\title{
Evolution of the Concept of Sensory Gardens in the Generally Accessible Space of a Large City: Analysis of Multiple Cases from Kraków (Poland) Using the Therapeutic Space Attribute Rating Method
}

\author{
Izabela Krzeptowska-Moszkowicz, Łukasz Moszkowicz (D) and Karolina Porada *(D)
}

check for updates

Citation: Krzeptowska-Moszkowicz,

I.; Moszkowicz, Ł.; Porada, K.

Evolution of the Concept of Sensory Gardens in the Generally Accessible Space of a Large City: Analysis of Multiple Cases from Kraków (Poland) Using the Therapeutic Space Attribute Rating Method. Sustainability 2021, 13, 5904. https:// doi.org/10.3390/su13115904

Academic Editors: Katarzyna Hodor, Magdalena Wilkosz-Mamcarczyk and Jan K. Kazak

Received: 30 April 2021

Accepted: 17 May 2021

Published: 24 May 2021

Publisher's Note: MDPI stays neutral with regard to jurisdictional claims in published maps and institutional affiliations.

Copyright: (c) 2021 by the authors. Licensee MDPI, Basel, Switzerland. This article is an open access article distributed under the terms and conditions of the Creative Commons Attribution (CC BY) license (https:/ / creativecommons.org/licenses/by/ $4.0 /)$.
Faculty of Architecture, Cracow University of Technology, 31-155 Krakow, Poland; ikrzepto@pk.edu.pl (I.K.-M.); lmoszkowicz@pk.edu.pl (Ł.M.)

* Correspondence: kporada@pk.edu.pl

\begin{abstract}
This paper presents a study on public gardens with sensory features located in Kraków (Poland). Data for the analysis of the facilities were obtained during site visits using observations. The paper uses a research method for the analysis of therapeutic outdoor areas in cities based on the evaluation of their attributes. This method makes it possible to characterise features of objects as well as their value. It is a practical tool, which enables an in-depth analysis of public spaces. The study showed that public gardens with sensory features located in Kraków have significant deficiencies, which make it impossible to fully exploit the potential of the sensory space.
\end{abstract}

Keywords: therapeutic space; sensory garden; Kraków; public space; rating method

\section{Introduction}

Sensory gardens are typically described as a type of therapeutic garden, e.g., in the cross-sectional work by Winterbottom and Wagenfeld [1]. These types of gardens are created in public spaces and sometimes form part of therapy and healthcare centres. This trend grew even more when it was demonstrated that the view of greenery and the presence in a green space have a positive impact on patient health [2]. Initially, sensory gardens were designed primarily with blind people in mind (the oldest included the touch- and smell-focused garden at the John J. Tyler Arboretum, in Lima (1949, PA, USA), or the fragrance garden at the Cambridge University Botanical Garden (1960, Cambridge, UK)), but over time they were tailored to all visitors, regardless of ability or disability, which was labelled universal design [1]. Few detailed studies about them have been published, and the existing literature focuses mostly on cases from specific countries. Such works include those of Hussein [3], which focused on therapeutic sensory gardens accompanying educational facilities for the disabled in Great Britain. Gonzales and Kirkevold discussed the problem of therapeutic gardens accompanying care homes in Norway [4]. An analysis of various therapeutic sensory gardens in Lithuania was presented by Balode [5].

Contemporary sensory gardens are often intended to stimulate various human senses. Apart from the five basic senses - touch, taste, smell, hearing, and vision-the holistic sensory systems of the human body have also become a focus. Winterbottom and Wagenfeld argue that the designs of therapeutic gardens should focus on the relationship between gardens and movement, balance, and touch [1]. This appears to be of particular significance in sensory healing gardens.

The Sensory Trust (from the United Kingdom) defines a sensory garden as 'a selfcontained area that concentrates a wide range of sensory experiences. Such an area, if designed well, provides a valuable resource for a wide range of uses, from education to recreation' [6]. This definition does not categorise stimuli and does not focus on how many and which senses should be used to receive them, focusing instead on an area's potential 
to generate stimuli. With this definition, sensory gardens can have a variety of uses, the therapeutic use not being the primary one. It better characterises sensory gardens designed in public spaces, i.e., where such gardens accompany various places and institutions (e.g., at housing estates, at schools, as parts of public parks and gardens) and have a diverse set of users.

Hussein (2009) noted that sensory gardens should be designed so as to be perceived and experienced from up close, using all of one's senses [7]. This type of garden allows the user to develop a close and highly individualised relationship with each of its elements. The senses can be influenced by various elements, such as vegetation, paving, or outdoor furniture [1] — especially sound, tactile, and kinetic elements such as reliefs or musical instruments. Water is also an essential element in all therapeutic gardens. Its basic property is to feed the soil and the plants. Winterbottom and Wagenfeld point out that a good practice in therapeutic gardens is to establish bioswales and raingardens, which not only support rainwater management but also bring birds, butterflies, and dragonflies into the garden [1]. Water features can also have sensory significance. The sound of water in a stream, fountain, or cascade is a factor that affects the sense of hearing.

Polish-language literature features few works on sensory gardens, which could be associated with their being relatively new. Our search of academic literature indicates that interest in the topic of sensory gardens in Poland emerged after 2000, and one of the first authors was Pawłowska [8]. In publications from the period 2010-2020, a division can be seen between literature describing Polish case studies and the problem of using sensory gardens for the rehabilitation of users with visual impairment. A study of various Polish therapeutic garden cases, including sensory gardens, can be found in publications by Dudkiewicz et al. [9], Górska-Kłęk [10], or Trojanowska [11]. Studies of sensory gardens as spaces for the visually impaired were published by Dabski \& Dudkiewicz [12], Trojanowska [13], Woźny \& Lauda [14], and Zajadacz \& Lubarska [15], who analysed selected Polish cases.

As for generally available spaces, sensory gardens were found to have an even poorer representation in Polish-language literature. The idea of aligning sensory spaces with the structure of therapeutic parks was proposed by Trojanowska [11], who argued that multi-sensory stimulation is the fundamental purpose of such parks and is associated with creating separate spaces dedicated to sensory impacts. A multiple case study of small sensory gardens located in the most densely developed parts of New York was presented by Pawłowska [8]. This study underscores their role as spaces that positively influence human wellbeing, especially of individuals who work in downtown areas of large cities, who are the typical users of such gardens. Sensory gardens in cities can thus play the role of restorative gardens, i.e., places that offer conditions favourable to reattaining the body's internal balance (homeostasis), which can improve emotional and psychological wellbeing, for instance by reducing stress [16]. Krzeptowska-Moszkowicz et al. [17] discussed creating sensory gardens that would be friendly both to humans and animals in large cities, as this could aid in enhancing the scope of positive stimuli that affect the human senses.

\section{Evolution of the Idea of Sensory Gardens in Poland}

Sensory gardens are closely tied with the human senses but can have different definitions, as our perspective on this garden type is evolving. One of the more often-quoted definitions in Polish-language literature states that 'mianem ogrodu sensorycznego określa się kompozycje tak zaprojektowana, aby bodźce pozawzrokowe były użyte celowo i to w większym natężeniu niż zwykle' (a sensory garden is a composition designed so that non-visual stimuli are used intentionally and at a much greater intensity than usual) [8]. It classifies sensory gardens as layouts addressed primarily to the blind, which does not exclude their use by all visitors. This is a view that stems from the original perceptions of these gardens as places primarily intended for the visually impaired.

The construction of sensory gardens in Poland began only two decades ago. In 2008, Pawłowska wrote that 'the idea of sensory gardens was not yet popular in Poland' [8]. 
Design work on sensory gardens was also viewed as a certain form of experimentation. In the first decade of the twenty-first century, this idea was already present in Poland, and conceptual designs were created at universities-e.g., at the Cracow University of Technology, some students prepared concepts for sensory gardens as part of their diploma theses under Pawłowska's guidance [18], although completed projects with such gardens were far from common, especially in public spaces.

The first projects to focus on generally accessible spaces in Poland were sites near national park headquarters and as parts of arboretums. They included: the Environmental Garden of the Senses near the Mouth of the Warta National Park Directorate Building, which had educational features targeting children and young people (2000), the Garden of the Senses near the Babia Góra National Park headquarters building in Zawoja (2007), with amenities for the disabled, including the blind, and the Sensory Garden in the Arboretum and Physiography Facility in Bolestraszyce (2008), which was also adapted to the needs of the disabled, including blind people. During this initial period, the first generally accessible sensory gardens in Poland were located outside of large cities. They were also linked with educational facilities. Only during the second decade of the twenty-first century did such gardens begin to appear in cities, associated with functions that were not educational. Their scope of use was also extended, which brought them closer to the definition of sensory gardens proposed by the Sensory Trust. In Kraków, the establishment of gardens with sensory features and located in public spaces has only been practised fora couple of years, which makes them relatively new facilities, dating from the period between 2013 and 2020, but more are being planned.

Large cities, as areas with a mosaic of places with a diverse range of functions, are dedicated to specific forms of activity. We can thus ask whether sensory gardens are built in spaces with different uses, or whether they are associated with a specific type of urban space. In this paper, we analyse the case of Kraków, one of Poland's largest cities. The objective of this paper was also to characterise and assess gardens with sensory features and located in Kraków as therapeutic spaces, with the use of a specific analytical tool.

\section{Object of Study}

Kraków is Poland's second-largest city, the largest being Warsaw. Its area is around $327 \mathrm{~km}^{2}$, and its population is around 780 thousand [19]. Kraków is a geomorphologically varied city. Various geographic and phytogeographic regions come into contact here [20].

The city's urban greenery system consists of natural greenery that comprises $7.88 \%$ of the city's area, with forests making up 6.04\%. Apart from forests, these areas also include complexes of aquatic and epilithic plants, as well as naturally growing plants. Urban greenery also includes semi-natural plant complexes such as meadows and pastures, which cover $7.39 \%$ of the city's area. There is also anthropogenic plant cover, which constitutes $36 \%$ of the city, and includes: fields, orchards, allotment gardens, and ruderal plants. This type of greenery also accompanies developed areas and household gardens and amounts to $29.11 \%$ of Kraków. Landscaped greenery covers only $13.47 \%$ of the city's area and includes public parks, fortress greenery, cemetery greenery, greenery accompanying sports grounds, streets, Jordan gardens (in Poland, this name is given to green areas established mainly in cities, intended for children and young people), and housing estates [21].

Based on the Polish-language literature and our own investigation, we determined that out of all Polish cities, Kraków had the most publicly available gardens with sensory features. Most of these gardens have never been analysed or mentioned in the Polishlanguage literature, as they were built relatively recently. The following gardens of this type can be found in Kraków (list by date of completion-garden area measurements were performed based on orthophotomaps: the area values are therefore estimates), the location is shown on the map (Figure 1):

(A) 'Zapachowo' - fragrance garden in the S. Lem Educational Park (2013)—ca. $742 \mathrm{~m}^{2}$;

(B) Sensory Garden at the Piaski Nowe housing estate (2019)—ca. $903 \mathrm{~m}^{2}$ (Figure 2); 
(C) Garden with sensory features near the J. Czapski Musuem (2018-2019)—ca. $260 \mathrm{~m}^{2}$ (Figure 3);

(D) Sensory garden with a sensory path in Tysiąclecia Park (2020)—ca. $1840 \mathrm{~m}^{2}$;

(E) Sensory garden in Reduta Park (2020) - ca. $2385 \mathrm{~m}^{2}$;

(F) Playground with sensory features in Jordan Park (built gradually, mostly in recent years)—ca. $2800 \mathrm{~m}^{2}$.

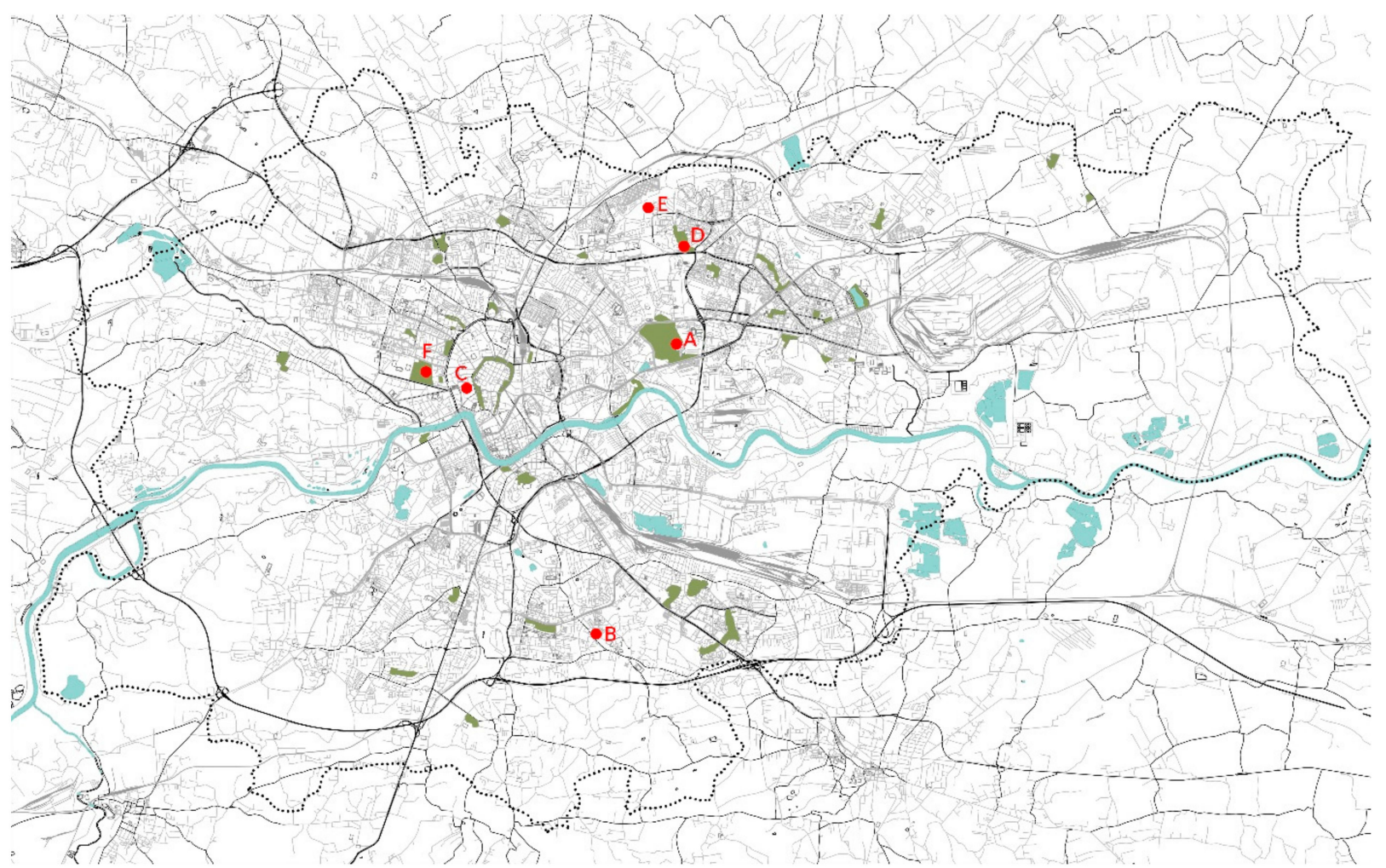

Figure 1. Placement of existing gardens with sensory features (A-F) in Kraków. City parks have been marked in green.

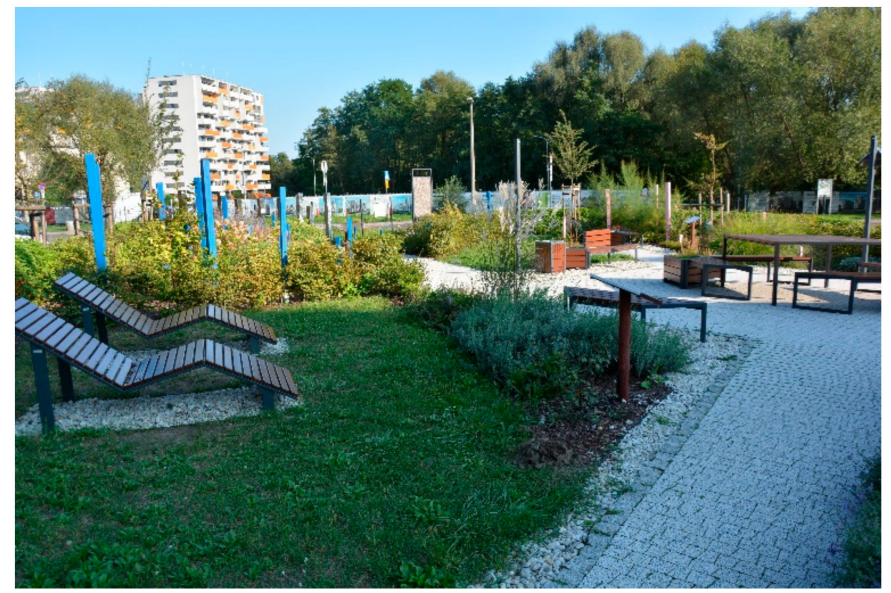

Figure 2. Sensory Garden at the Piaski Nowe housing estate, phot. Krzeptowska-Moszkowicz I., 2021. 


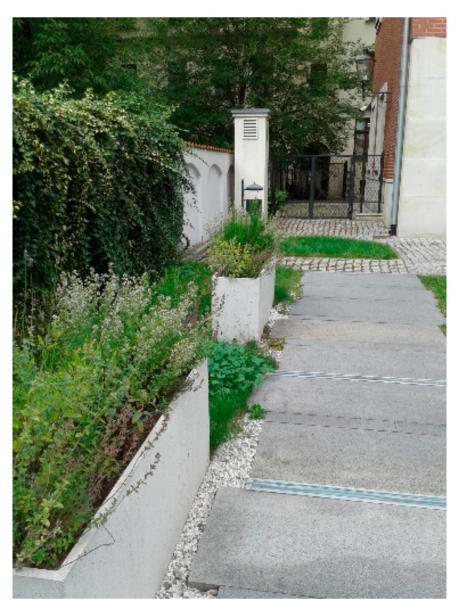

Figure 3. Garden with sensory features near the J. Czapski Musuem, phot. Porada K., 2020.

The existing sensory gardens in Kraków are small spaces within the urban tissue. The first garden of this type in the city was located near an educational building, which aligned with the initial trend in Poland. Gardens in different settings, e.g., in city parks, started to be built later. In our study we used material procured during visits to each site, which were conducted between 2019 and 2021, during spring and summer periods (due to vegetation). These were single visits, lasting several hours each, during which we conducted an inventory of sensory elements. The visits also allowed us to obtain specific data used to characterise each garden and to collect photographic material that can be of aid in analysing and illustrating specific problems (Figures 2 and 3).

\section{Research Method}

To determine the spaces where gardens with sensory features are located, we analysed the setting of each of their locations. We did this during on-site analyses.

Afterwards, we used a modified version of Trojanowska's method [22], assuming that essential values of therapeutic spaces-in the form of green areas-are comparable. This method was used to analyse public areas in cities, which is another argument in favour of using it to assess the generally accessible gardens with sensory features under study. The method is based on attribute analysis. The attribute was characterised as 'a feature of space or the presence of a type of equipment' [22]. The method assumes that as the number of attributes present in an area increases, so does its therapeutic potential.

Trojanowska used this method to analyse the therapeutic potential of parks, which is why it was necessary to adapt it to highly specific features, namely sensory gardens.

Well-designed sensory gardens should be characterised by the following distinctive characteristics [15]:

- they should be designed with the intent to stimulate human senses;

- they should form a complete whole, isolated from the surroundings;

- they should affect all the senses;

- they should focus on non-visual stimulation;

- apart from sense-stimulating plants, they should also feature other elements that stimulate the senses.

Additional elements can be added to this list:

- they should be animal-friendly, as the presence of animals increases the scope of positive stimuli [17];

- they should be equipped with water features, because of their sonic properties and their importance for plants and animals;

- they should have dedicated use indications that facilitate experiencing the garden from up close [17]; 
It was necessary to account for the characteristics presented above in the attribute set used to rate the garden. This was possible as the method was not designed as a finite tool, allowing for the addition of attributes.

After analysing the attributes listed by Trojanowska and comparing them with the characteristics of sensory gardens, we found that there was a significant difference concerning one element. Sensory gardens are spaces that are isolated from the surroundings, as experiencing them is oriented inwards, towards perception from up close, while large green areas such as parks are mainly focused outwards, on perceiving distant vistas, including those from outside of a given park's space. This was accounted for in the attribute set, with only a small number of attributes being removed, as we decided that their use in rating sensory gardens was not justified. The remaining attributes, as used by Trojanowska, remained unchanged, with some being combined, as it was possible to rate them together. These included 'elements that indirectly affect the comfort of use of the space: access to food, drink, toilets and others'. We did not find it justified to rate each of these elements separately in the case of sensory gardens, as they all determine user comfort and are often provided in a set (e.g., by the coffee shop in the garden of the J. Czapski Museum, as well as in Reduta Park).

Trojanowska segregated the attributes she had selected by assigning them to design stages - the same approach was used here, with the following stages: functional programme, functio-spatial structure, design of internal spaces, architectural form and place-making. We also accounted for sustainability criteria.

This method allows for characterising a garden's features and rating its value. It is a useful analytical tool, as it allows for identifying a garden's specific weaknesses as a therapeutic space. The less attributes, the lower the therapeutic functionality of such a space, and the user can derive less benefits from being in it.

\section{Results}

\subsection{Location of Kraków's Gardens with Sensory Features and Their Users}

Based on an analysis of the surroundings of Kraków's gardens with sensory features, we isolated the following urban activity zones (Table 1).

Table 1. Overview of Kraków's gardens with sensory features and an analysis of their surroundings with urban activity zones isolated.

\begin{tabular}{|c|c|c|c|c|}
\hline $\begin{array}{c}\text { Garden with } \\
\text { Sensory Features }\end{array}$ & General Overview & Location Overview & Use, Users & $\begin{array}{c}\text { Urban Activity } \\
\text { Zone }\end{array}$ \\
\hline $\begin{array}{l}\text { (A) in the } \\
\text { Educational S. Lem } \\
\text { Park }\end{array}$ & $\begin{array}{l}\text { The garden has a } \\
\text { freeform composition } \\
\text { and consists of a path } \\
\text { that meanders between } \\
\text { fragrant plants }\end{array}$ & $\begin{array}{l}\text { The garden is a part of a sensory } \\
\text { educational park that } \\
\text { familiarises users with the laws } \\
\text { of physics and that features } \\
\text { several dozen installations for } \\
\text { personal experimentation }\end{array}$ & $\begin{array}{l}\text { Learning through play, } \\
\text { primarily for children, } \\
\text { the youth, and adults }\end{array}$ & Educational zone \\
\hline $\begin{array}{l}\text { (B) accompanying } \\
\text { the J. Czapski } \\
\text { Museum }\end{array}$ & $\begin{array}{l}\text { The garden has a } \\
\text { geometric layout and } \\
\text { consists of a large, } \\
\text { square lawn and a path } \\
\text { that runs around it and } \\
\text { leads to the museum } \\
\text { building. There are tall } \\
\text { pots, mostly with } \\
\text { fragrant plants and } \\
\text { herbs, along the path }\end{array}$ & $\begin{array}{l}\text { The garden is located in the city } \\
\text { centre and belongs to the J. } \\
\text { Czapski } \\
\text { Museum grounds } \\
\text { It was designed as a place } \\
\text { intended for the museum's } \\
\text { supplementary events. The } \\
\text { building's outer wall is used as a } \\
\text { screen for film screenings, and } \\
\text { there is also a coffee shop in the } \\
\text { garden. There is another } \\
\text { Museum nearby, named after E. } \\
\text { Hutten-Czapski }\end{array}$ & $\begin{array}{l}\text { Cultural activity } \\
\text { intended for visitors to } \\
\text { the city and its } \\
\text { residents }\end{array}$ & $\begin{array}{l}\text { Cultural and } \\
\text { tourist zone }\end{array}$ \\
\hline
\end{tabular}


Table 1. Cont.

\begin{tabular}{|c|c|c|c|c|}
\hline $\begin{array}{c}\text { Garden with } \\
\text { Sensory Features }\end{array}$ & General Overview & Location Overview & Use, Users & $\begin{array}{c}\text { Urban Activity } \\
\text { Zone }\end{array}$ \\
\hline $\begin{array}{l}\text { (C) at the Nowe } \\
\text { Piaski housing } \\
\text { estate }\end{array}$ & $\begin{array}{l}\text { It was designed with } \\
\text { central paths extending } \\
\text { from a central section } \\
\text { and leading to various } \\
\text { garden interiors. It has } \\
\text { a wealth of plants and } \\
\text { small meadows } \\
\text { covered with grass and } \\
\text { surrounded by } \\
\text { greenery }\end{array}$ & $\begin{array}{l}\text { The garden is located on a } \\
\text { typical block housing estate } \\
\text { distinctive for large } \\
\text { Polish cities. The garden is } \\
\text { surrounded by housing blocks, } \\
\text { streets, and parking lots }\end{array}$ & $\begin{array}{l}\text { Local communal } \\
\text { activity, it is also used } \\
\text { as a meeting space and } \\
\text { to stimulate activity } \\
\text { among seniors }\end{array}$ & $\begin{array}{l}\text { Urban housing } \\
\text { estate resident } \\
\text { activity zone }\end{array}$ \\
\hline $\begin{array}{l}\text { (D) in Tysiąclecia } \\
\text { Park }\end{array}$ & $\begin{array}{l}\text { The garden consists of } \\
\text { several sections, its } \\
\text { composition is } \\
\text { part-freeform and } \\
\text { part-geometric. }\end{array}$ & $\begin{array}{l}\text { The garden is located in the } \\
\text { centre of a large city park }\end{array}$ & $\begin{array}{l}\text { Outdoor exercise and } \\
\text { rest among greenery } \\
\text { for local citizens }\end{array}$ & $\begin{array}{l}\text { Recreational zone } \\
\text { in an urban green } \\
\text { area }\end{array}$ \\
\hline
\end{tabular}

The garden is located on a slope; most of it is geometric. It features large, narrow beds with fruit bushes and low beds mostly filled with

(E) in Reduta Park fragrant herbs. The garden features a coffee shop with a roof with a gravel surface and low planters with fragrant plants. The roof can be reached via stairs.
The garden is located in a large city park
Outdoor exercise and rest among greenery for local citizens
Recreational zone in an urban green area
The garden was built gradually and consists of a sand garden, a section of wooden play equipment for children, a fountain with jets in the pavement surface, and a green labyrinth.
The garden is located in a large park which has been dedicated to children's and youth activity from its inception.
Stimulating children and the youth to lead an active and healthy lifestyle
A zone dedicated to sports activity among children and the youth

The listing above shows that the gardens under analysis are not assigned to any single specific urban activity zone, but instead are located in very different zones within the urban tissue, and as such are dedicated to different user groups. Each of the gardens has specific intended users, ranging from the local community to the general population of the city and tourists. These gardens are therefore directed towards specific users and there is a certain specialisation in this regard. However, when looking at them holistically, it can be said that they are areas of activity for every age group — children, youth, adults, and seniors.

None of the gardens under analysis had any distinguishing features that would suggest an intention of catering to the blind or visually impaired (like the first sensory gardens to be built in Poland and around the world). They lacked dedicated amenities for these groups. It was probably assumed that persons with visual impairments were not intended to be the main users of these gardens.

\subsection{Sensory Stimulation in Kraków's Sensory Gardens}

While accounting for the evolution of the idea of sensory gardens and the projects built in Kraków, it was found that the gardens with sensory features that existed there at 
the time of this study were based primarily on the five basic human senses (Table 2). There were very few elements that stimulated other senses.

Table 2. Listing of sensory stimuli in Kraków's gardens with sensory features.

\begin{tabular}{|c|c|c|c|c|c|c|}
\hline $\begin{array}{c}\text { Garden with } \\
\text { Sensory Features }\end{array}$ & Taste & Touch & Sight & Hearing & Smell & Others \\
\hline $\begin{array}{l}\text { (A) in the } \\
\text { Educational S. } \\
\text { Lem Park }\end{array}$ & None & $\begin{array}{l}\text { There is a sensory } \\
\text { path near the } \\
\text { garden-tactile } \\
\text { sensations in feet }\end{array}$ & $\begin{array}{l}\text { Flowers, } \\
\text { greenery, plants }\end{array}$ & $\begin{array}{l}\text { People } \\
\text { laughing, birds } \\
\text { singing }\end{array}$ & $\begin{array}{l}\text { Large areas } \\
\text { of fragrant } \\
\text { herbs }\end{array}$ & $\begin{array}{l}\text { There is a } \\
\text { plant-based } \\
\text { labyrinth near the } \\
\text { garden }\end{array}$ \\
\hline $\begin{array}{l}\text { (B) } \\
\text { accompanying } \\
\text { the J. Czapski } \\
\text { Museum }\end{array}$ & Fruits & $\begin{array}{l}\text { The touch of } \\
\text { grass, plants, } \\
\text { sensory } \\
\text { path-tactile } \\
\text { sensations in feet }\end{array}$ & $\begin{array}{l}\text { Colours of } \\
\text { flowers, fruits, } \\
\text { narrow mirrors } \\
\text { that reflect } \\
\text { plants }\end{array}$ & Insect buzzing & $\begin{array}{l}\text { Fragrant } \\
\text { herbs and } \\
\text { flowers }\end{array}$ & $\begin{array}{l}\text { Wigwam from } \\
\text { willow branches, } \\
\text { isolated } \\
\text { meadows with } \\
\text { grass, a small } \\
\text { sensory path }\end{array}$ \\
\hline $\begin{array}{l}\text { (C) at the Nowe } \\
\text { Piaski housing } \\
\text { estate }\end{array}$ & $\begin{array}{l}\text { The taste of } \\
\text { herbs, nearby } \\
\text { coffee shop }\end{array}$ & $\begin{array}{l}\text { Ability to touch } \\
\text { plants with } \\
\text { different textures }\end{array}$ & $\begin{array}{l}\text { Green and } \\
\text { white-the } \\
\text { plants and the } \\
\text { surroundings }\end{array}$ & Insect buzzing & $\begin{array}{l}\text { Fragrant } \\
\text { herbs and } \\
\text { flowers }\end{array}$ & None \\
\hline $\begin{array}{l}\text { (D) in Tysiąclecia } \\
\text { Park }\end{array}$ & None & $\begin{array}{l}\text { The touch of } \\
\text { perennial plants, } \\
\text { sensory } \\
\text { path-tactile } \\
\text { sensations in feet }\end{array}$ & $\begin{array}{l}\text { Colours of } \\
\text { flowers }\end{array}$ & $\begin{array}{l}\text { The sound of } \\
\text { water (a } \\
\text { fountain) }\end{array}$ & $\begin{array}{l}\text { Bitterling, } \\
\text { the smell of } \\
\text { herbs and } \\
\text { flowers }\end{array}$ & $\begin{array}{l}\text { Elements in the } \\
\text { form of a line net }\end{array}$ \\
\hline $\begin{array}{l}\text { (E) in Reduta } \\
\text { Park }\end{array}$ & Fruits & None & $\begin{array}{l}\text { Colours of } \\
\text { flowers }\end{array}$ & Insect buzzing & $\begin{array}{l}\text { Smell of } \\
\text { herbs }\end{array}$ & $\begin{array}{l}\text { Observation deck } \\
\text { with gravel } \\
\text { surface }\end{array}$ \\
\hline $\begin{array}{l}\text { (F) in H. Jordan } \\
\text { Park }\end{array}$ & None & $\begin{array}{l}\text { Touch of sand, } \\
\text { water, and wood }\end{array}$ & $\begin{array}{l}\text { Green of plants, } \\
\text { clear water }\end{array}$ & $\begin{array}{l}\text { Sound of steps } \\
\text { on wooden } \\
\text { surfaces, birds } \\
\text { singing, the } \\
\text { sound of water }\end{array}$ & None & $\begin{array}{l}\text { Labyrinth made } \\
\text { of plants }\end{array}$ \\
\hline
\end{tabular}

\subsection{Garden Attribute Analysis}

We performed our analysis using the methodology prepared by Trojanowska [22]. Initially, we described the form the attributes took in each garden. To rate the presence of attributes (using numbers), we used the following scale:

- 1 -the attribute was present, and its potential was being used well,

- $\quad 0.5$ - the attribute was present, but it was not used to its full potential,

- $\quad 0$ - the attribute was not present.

The assessment of each object was based on observations. Here we used an enhanced rating (by adding the 0.5 value) so that we could assess whether an attribute's potential was fully introduced into the garden's space (Tables 3 and 4). The occurrence of the attributes characterising the therapeutic spaces in sensory gardens in Krakow is also presented as a percentage in the graphs (Figure 4). 
Table 3. Analysis of the attributes of Kraków's gardens with sensory features-the first group of attributes.

\begin{tabular}{|c|c|c|c|c|c|c|c|}
\hline \multicolumn{8}{|c|}{ The First Group of Attributes } \\
\hline & & (A) & (B) & (C) & (D) & (E) & (F) \\
\hline $\begin{array}{c}\text { Functional } \\
\text { Programme }\end{array}$ & Attribute & & & & & & \\
\hline \multirow{3}{*}{$\begin{array}{l}\text { (a) Enabling } \\
\text { physical and } \\
\text { psychological } \\
\text { regeneration }\end{array}$} & $\begin{array}{l}\text { Places for rest } \\
\text { that facilitate } \\
\text { experiencing } \\
\text { the } \\
\text { surroundings } \\
\text { from up close }\end{array}$ & $\begin{array}{l}\text { YES/NO (0.5) } \\
\text { too few } \\
\text { benches, but } \\
\text { they are deep } \\
\text { in the garden }\end{array}$ & $\begin{array}{l}\text { YES (1) many } \\
\text { seats in various } \\
\text { parts of the } \\
\text { garden, there is } \\
\text { also a small } \\
\text { meadow with } \\
\text { sunbeds }\end{array}$ & $\begin{array}{l}\text { YES/NO }(0.5) \\
\text { there are seats } \\
\text { on a platform, } \\
\text { but no isolated } \\
\text { places or } \\
\text { places near } \\
\text { plants }\end{array}$ & $\begin{array}{l}\text { YES/NO }(0.5) \\
\text { there are seats } \\
\text { in various } \\
\text { places, but } \\
\text { usually along } \\
\text { the main path }\end{array}$ & $\begin{array}{l}\text { YES/NO (0.5) } \\
\text { too few } \\
\text { benches, only } \\
\text { in selected } \\
\text { places and } \\
\text { arranged } \\
\text { linearly }\end{array}$ & $\begin{array}{l}\text { YES/NO (0.5) } \\
\text { too few } \\
\text { benches }\end{array}$ \\
\hline & $\begin{array}{l}\text { Isolation from } \\
\text { the urban } \\
\text { environment, } \\
\text { noise, smells, } \\
\text { and the } \\
\text { pressure of } \\
\text { time and fast } \\
\text { living }\end{array}$ & $\begin{array}{l}\text { YES (1) the } \\
\text { garden is at the } \\
\text { edge of a } \\
\text { science garden } \\
\text { and faces the } \\
\text { park }\end{array}$ & $\begin{array}{l}\text { YES (1) densely } \\
\text { placed plants } \\
\text { partially } \\
\text { insulate from } \\
\text { streets, but } \\
\text { there are also } \\
\text { places deeper } \\
\text { in the garden }\end{array}$ & $\begin{array}{l}\text { YES (1) the } \\
\text { garden is } \\
\text { located in an } \\
\text { interior } \\
\text { courtyard }\end{array}$ & $\begin{array}{l}\mathrm{NO}(0) \text { a busy } \\
\text { path runs } \\
\text { through the } \\
\text { garden, no } \\
\text { plants along } \\
\text { the edges }\end{array}$ & $\begin{array}{l}\text { YES/NO (0.5) } \\
\text { frequented } \\
\text { paths run } \\
\text { through the } \\
\text { garden, and } \\
\text { there is a } \\
\text { playground } \\
\text { nearby, but the } \\
\text { park itself is } \\
\text { isolated from } \\
\text { busy streets }\end{array}$ & $\begin{array}{l}\text { YES/NO }(0.5) \\
\text { the garden is } \\
\text { near the park's } \\
\text { outer fence, } \\
\text { but there are } \\
\text { bushes and } \\
\text { trees here }\end{array}$ \\
\hline & $\begin{array}{l}\text { Ability to } \\
\text { easily observe } \\
\text { animals or } \\
\text { people }\end{array}$ & $\begin{array}{l}\text { YES/NO }(0.5) \\
\text { insects-there } \\
\text { are taller } \\
\text { bushes, but } \\
\text { many plants } \\
\text { are close to the } \\
\text { soil surface }\end{array}$ & $\begin{array}{l}\text { YES (1) insects } \\
\text { and } \\
\text { birds-there } \\
\text { are both taller } \\
\text { bushes and } \\
\text { perennials, as } \\
\text { well as } \\
\text { bench-side } \\
\text { plants }\end{array}$ & $\begin{array}{l}\text { YES }(1) \text { insects, } \\
\text { as plants are in } \\
\text { taller pots }\end{array}$ & $\begin{array}{l}\text { YES/NO (0.5) } \\
\text { there are taller } \\
\text { perennials, but } \\
\text { most plants are } \\
\text { short }\end{array}$ & $\begin{array}{l}\text { NO }(0) \text { - the } \\
\text { benches are } \\
\text { placed in a way } \\
\text { that prevents a } \\
\text { comfortable } \\
\text { observation of } \\
\text { the nearby } \\
\text { park area }\end{array}$ & $\begin{array}{l}\text { YES (1) ability } \\
\text { to observe } \\
\text { children at } \\
\text { play, or birds }\end{array}$ \\
\hline $\begin{array}{l}\text { (b) Facilitating } \\
\text { social contact }\end{array}$ & $\begin{array}{l}\text { Ability to meet } \\
\text { as a group }\end{array}$ & $\begin{array}{l}\text { YES/NO (0.5) } \\
\text { there is a small } \\
\text { space with } \\
\text { three benches, } \\
\text { but the main } \\
\text { path crosses } \\
\text { through it, } \\
\text { which can } \\
\text { make } \\
\text { conversing } \\
\text { difficult }\end{array}$ & $\begin{array}{l}\text { YES (1) there is } \\
\text { a meeting } \\
\text { space; benches } \\
\text { are often } \\
\text { placed in pairs } \\
\text { and at an angle, } \\
\text { facilitating eye } \\
\text { contact and } \\
\text { conversation }\end{array}$ & $\begin{array}{l}\text { YES (1) there is } \\
\text { a space for } \\
\text { meetings-a } \\
\text { terrace with } \\
\text { chairs and } \\
\text { tables that can } \\
\text { be rearranged }\end{array}$ & $\begin{array}{l}\text { YES/NO (0.5) } \\
\text { meetings are } \\
\text { possible, but } \\
\text { usually for two } \\
\text { people- } \\
\text { benches and } \\
\text { chairs are } \\
\text { placed in pairs }\end{array}$ & $\begin{array}{l}\text { YES/NO (0.5) } \\
\text { ability to meet } \\
\text { at a coffee } \\
\text { shop, but the } \\
\text { sensory spaces } \\
\text { do not } \\
\text { facilitate this }\end{array}$ & $\begin{array}{l}\text { YES (1) the } \\
\text { entire space } \\
\text { allows group } \\
\text { play }\end{array}$ \\
\hline \multirow[t]{2}{*}{$\begin{array}{l}\text { (c) Facilitating } \\
\text { physical } \\
\text { activity }\end{array}$} & $\begin{array}{l}\text { Places for play } \\
\text { and recreation }\end{array}$ & $\begin{array}{l}\text { YES (1) a large } \\
\text { lawn, with } \\
\text { equipment for } \\
\text { performing } \\
\text { experiments } \\
\text { nearby }\end{array}$ & $\begin{array}{l}\text { YES (1) a } \\
\text { meadow in a } \\
\text { garden with } \\
\text { sunbeds and a } \\
\text { wigwam made } \\
\text { of living } \\
\text { willow } \\
\text { branches for } \\
\text { children }\end{array}$ & $\begin{array}{l}\text { YES/NO (0.5) } \\
\text { there is a lawn, } \\
\text { but due to the } \\
\text { proximity of a } \\
\text { Museum it is } \\
\text { not used for } \\
\text { physical } \\
\text { activity }\end{array}$ & $\begin{array}{l}\text { YES (1) } \\
\text { features with a } \\
\text { line net } \\
\text { suspended } \\
\text { from metal } \\
\text { frames; } \\
\text { extensive } \\
\text { lawns nearby }\end{array}$ & $\begin{array}{l}\text { YES/NO }(0.5) \\
\text { there are lawns, } \\
\text { but the site is } \\
\text { on a slope, } \\
\text { which excludes } \\
\text { several activity } \\
\text { types }\end{array}$ & $\begin{array}{l}\text { YES (1) the } \\
\text { entire area } \\
\text { facilitates play } \\
\text { for children } \\
\text { and their } \\
\text { caretakers }\end{array}$ \\
\hline & $\begin{array}{l}\text { Place } \\
\text { dedicated to } \\
\text { gardening } \\
\text { classes or } \\
\text { hortitherapy }\end{array}$ & $\begin{array}{l}\text { NO } \\
(0) \text {-absent }\end{array}$ & $\begin{array}{l}\text { YES (1) a large } \\
\text { table for } \\
\text { classes in the } \\
\text { central part }\end{array}$ & $\begin{array}{l}\mathrm{NO} \\
(0) \text {-absent }\end{array}$ & $\begin{array}{l}\text { NO } \\
(0) \text {-absent }\end{array}$ & $\begin{array}{l}\mathrm{NO} \\
(0) \text {-absent }\end{array}$ & $\begin{array}{l}\mathrm{NO} \\
(0) \text {-absent }\end{array}$ \\
\hline
\end{tabular}


Table 3. Cont

\begin{tabular}{|c|c|c|c|c|c|c|c|}
\hline \multicolumn{8}{|c|}{ The First Group of Attributes } \\
\hline & & (A) & (B) & (C) & (D) & (E) & (F) \\
\hline $\begin{array}{l}\text { Functional } \\
\text { Programme }\end{array}$ & Attribute & & & & & & \\
\hline \multirow{6}{*}{$\begin{array}{l}\text { (d) Meeting } \\
\text { essential user } \\
\text { needs }\end{array}$} & $\begin{array}{l}\text { Safety in the } \\
\text { garden space }\end{array}$ & $\begin{array}{l}\text { YES (1) the } \\
\text { garden is } \\
\text { located in a } \\
\text { larger, fenced } \\
\text { science garden }\end{array}$ & $\begin{array}{l}\text { YES (1) the } \\
\text { garden is } \\
\text { fenced }\end{array}$ & $\begin{array}{l}\text { YES }(1) \text { the } \\
\text { garden is close } \\
\text { to the Museum, } \\
\text { in its internal } \\
\text { courtyard }\end{array}$ & $\begin{array}{l}\mathrm{NO}(0) \text { lack of } \\
\text { isolation from } \\
\text { the remainder } \\
\text { of the park }\end{array}$ & $\begin{array}{l}\text { NO (0) lack of } \\
\text { isolation from } \\
\text { the remainder } \\
\text { of the park }\end{array}$ & $\begin{array}{l}\text { YES (1) the site } \\
\text { is fenced with } \\
\text { a low fence }\end{array}$ \\
\hline & $\begin{array}{l}\text { Safety in direct } \\
\text { contact with } \\
\text { plants }\end{array}$ & $\begin{array}{l}\text { YES }(0.5) \text { the } \\
\text { plants are safe, } \\
\text { but there are } \\
\text { also roses }\end{array}$ & $\begin{array}{l}\text { YES/NO }(0.5) \\
\text { most plants are } \\
\text { safe, but there } \\
\text { are also prickly } \\
\text { plants }\end{array}$ & $\begin{array}{l}\text { YES (1) safe } \\
\text { plants were } \\
\text { used, mainly } \\
\text { herbs }\end{array}$ & $\begin{array}{l}\text { YES/NO }(0.5) \\
\text { there are rose } \\
\text { bushes around } \\
\text { a fountain }\end{array}$ & $\begin{array}{l}\text { YES/NO (0.5) } \\
\text { safe plants } \\
\text { were used, but } \\
\text { there are } \\
\text { gooseberry } \\
\text { bushes }\end{array}$ & $\begin{array}{l}\text { YES (1) the } \\
\text { labyrinth is } \\
\text { made from safe } \\
\text { plants }\end{array}$ \\
\hline & $\begin{array}{l}\text { Seating or } \\
\text { shelter }\end{array}$ & $\begin{array}{l}\text { YES/NO (0.5) } \\
\text { there is shelter } \\
\text { under tree } \\
\text { canopies }\end{array}$ & $\begin{array}{l}\text { YES (1) shelter } \\
\text { under a sail } \\
\text { suspended } \\
\text { above the } \\
\text { garden's } \\
\text { central space }\end{array}$ & $\begin{array}{l}\text { YES (1) shelter } \\
\text { inside a coffee } \\
\text { shop that } \\
\text { opens towards } \\
\text { the garden }\end{array}$ & $\begin{array}{l}\text { YES }(0.5) \text { there } \\
\text { is shelter under } \\
\text { tree canopies }\end{array}$ & $\begin{array}{l}\text { YES (1) shelter } \\
\text { inside a coffee } \\
\text { shop }\end{array}$ & $\begin{array}{l}\text { YES/NO }(0.5) \\
\text { there is shelter } \\
\text { under tree } \\
\text { canopies }\end{array}$ \\
\hline & $\begin{array}{l}\text { Sunny and } \\
\text { shaded places }\end{array}$ & $\begin{array}{l}\text { YES/NO (0.5) } \\
\text { there are only } \\
\text { sunny spaces } \\
\text { in the garden }\end{array}$ & YES (1) & YES (1) & YES (1) & $\begin{array}{l}\text { YES/NO }(0.5) \\
\text { there are only } \\
\text { sunny spaces } \\
\text { in the garden }\end{array}$ & YES (1) \\
\hline & $\begin{array}{l}\text { Amenities for } \\
\text { the disabled }\end{array}$ & $\begin{array}{l}\text { NO }(0) \text { a gravel } \\
\text { path with solid } \\
\text { strips, but } \\
\text { turns are at an } \\
\text { angle that } \\
\text { make it } \\
\text { impossible for } \\
\text { wheelchair- } \\
\text { bound persons } \\
\text { to make them }\end{array}$ & $\begin{array}{l}\text { YES/NO }(0.5) \\
\text { wide paths, but } \\
\text { no amenities } \\
\text { for the blind }\end{array}$ & $\begin{array}{l}\text { YES/NO }(0.5) \\
\text { wide paths, but } \\
\text { no dedicated } \\
\text { amenities for } \\
\text { the blind }\end{array}$ & $\begin{array}{l}\text { YES/NO (0.5) } \\
\text { wide, even } \\
\text { paths, but no } \\
\text { dedicated } \\
\text { amenities for } \\
\text { the blind }\end{array}$ & $\begin{array}{l}\text { NO }(0) \text { the } \\
\text { garden is on a } \\
\text { slope, the } \\
\text { paths along } \\
\text { bushes are } \\
\text { narrow and } \\
\text { dead-ended, } \\
\text { which hinders } \\
\text { wheelchair } \\
\text { movement, } \\
\text { stairs to the } \\
\text { observation } \\
\text { deck }\end{array}$ & NO (0) absent \\
\hline & $\begin{array}{l}\text { Elements that } \\
\text { indirectly } \\
\text { affect comfort } \\
\text { of use: access } \\
\text { to food and } \\
\text { drink, toilets, } \\
\text { and others }\end{array}$ & $\begin{array}{l}\text { YES (1) they } \\
\text { are present in } \\
\text { the park }\end{array}$ & $\begin{array}{l}\text { YES/NO }(0.5) \\
\text { they are absent } \\
\text { in the park; } \\
\text { there are } \\
\text { bicycle stands } \\
\text { and waste bins }\end{array}$ & $\begin{array}{l}\text { YES (1) there is } \\
\text { a coffee shop } \\
\text { that opens } \\
\text { towards the } \\
\text { garden }\end{array}$ & $\begin{array}{l}\text { YES/NO (0.5) } \\
\text { there are } \\
\text { bicycle stands }\end{array}$ & $\begin{array}{l}\text { YES (1) there is } \\
\text { a coffee shop } \\
\text { with restrooms }\end{array}$ & $\begin{array}{l}\text { YES (1) they } \\
\text { are present in } \\
\text { the park }\end{array}$ \\
\hline $\begin{array}{l}\text { (e) Cognitive } \\
\text { support }\end{array}$ & $\begin{array}{l}\text { Features that } \\
\text { facilitate } \\
\text { education in } \\
\text { the garden }\end{array}$ & $\begin{array}{l}\text { YES (1) } \\
\text { plaques with } \\
\text { plant names }\end{array}$ & $\begin{array}{l}\text { YES (1) } \\
\text { information } \\
\text { boards that } \\
\text { also feature } \\
\text { plant names }\end{array}$ & $\mathrm{NO}(0)$ & $\begin{array}{l}\text { NO }(0) \text { no } \\
\text { plaques }\end{array}$ & $\begin{array}{l}\mathrm{NO}(0) \text { no } \\
\text { plaques }\end{array}$ & $\begin{array}{l}\text { YES/NO (0.5) } \\
\text { learning } \\
\text { through play } \\
\text { facilitated by } \\
\text { playground } \\
\text { equipment }\end{array}$ \\
\hline
\end{tabular}


Table 4. Analysis of the attributes of Kraków's gardens with sensory features—the second group of attributes.

\begin{tabular}{|c|c|c|c|c|c|c|c|}
\hline \multicolumn{8}{|c|}{ The Second Group of Attributes } \\
\hline & & (A) & (B) & (C) & (D) & (E) & (F) \\
\hline & Attribute & & & & & & \\
\hline \multirow[t]{2}{*}{$\begin{array}{l}\text { Functio-spatial } \\
\text { structure }\end{array}$} & $\begin{array}{l}\text { Isolation of the } \\
\text { garden from its } \\
\text { surroundings, } \\
\text { creating a } \\
\text { separate, } \\
\text { intimate space }\end{array}$ & YES/NO (0.5) & YES (1) & YES (1) & $\mathrm{NO}(0)$ & $\mathrm{NO}(0)$ & YES (1) \\
\hline & $\begin{array}{l}\text { Siting in a } \\
\text { place that } \\
\text { retains } \\
\text { fragrances and } \\
\text { sounds inside } \\
\text { the garden }\end{array}$ & $\begin{array}{l}\text { YES (1) there is } \\
\text { a hill near the } \\
\text { garden that } \\
\text { shelters it from } \\
\text { one side }\end{array}$ & $\begin{array}{l}\text { YES (1) plants } \\
\text { located around } \\
\text { the outer rim } \\
\text { of the garden } \\
\text { shelter it from } \\
\text { draughts }\end{array}$ & $\begin{array}{l}\text { YES (1) the } \\
\text { garden is } \\
\text { surrounded by } \\
\text { solid fences } \\
\text { and walls }\end{array}$ & $\begin{array}{l}\text { YES/NO }(0.5) \\
\text { the garden is in } \\
\text { a depressed } \\
\text { area, but has } \\
\text { no buffer } \\
\text { greenery to } \\
\text { protect it from } \\
\text { draughts }\end{array}$ & $\begin{array}{l}\text { YES/NO }(0.5) \\
\text { only partially } \\
\text { protected }\end{array}$ & $\mathrm{NO}(0)$ \\
\hline \multirow[t]{5}{*}{$\begin{array}{l}\text { Internal space } \\
\text { and } \\
\text { architectural } \\
\text { form design }\end{array}$} & $\begin{array}{l}\text { Garden } \\
\text { complexity, } \\
\text { presence of } \\
\text { various garden } \\
\text { interiors, } \\
\text { proper path } \\
\text { system }\end{array}$ & $\begin{array}{l}\text { YES/NO (0.5) } \\
\text { interesting } \\
\text { path course, no } \\
\text { interiors for } \\
\text { longer stays }\end{array}$ & $\begin{array}{l}\text { YES (1) the } \\
\text { garden is } \\
\text { divided into } \\
\text { interiors where } \\
\text { one can sit and } \\
\text { stay longer }\end{array}$ & $\begin{array}{l}\text { YES/NO (0.5) } \\
\text { the layout is } \\
\text { simple, the } \\
\text { path encircles a } \\
\text { lawn, but plant } \\
\text { pots are only } \\
\text { on one side }\end{array}$ & $\begin{array}{l}\text { YES (1) the } \\
\text { garden has } \\
\text { varied interiors } \\
\text { and each has } \\
\text { rest spaces }\end{array}$ & $\begin{array}{l}\text { YES/NO (0.5) } \\
\text { there are } \\
\text { diverse } \\
\text { interiors but no } \\
\text { paths, some } \\
\text { paths have } \\
\text { dead ends, } \\
\text { little room to } \\
\text { sit among the } \\
\text { plants }\end{array}$ & $\begin{array}{l}\text { YES/NO (0.5) } \\
\text { the path runs } \\
\text { through the } \\
\text { garden's } \\
\text { centre, which } \\
\text { allows easy } \\
\text { access to its } \\
\text { every part; } \\
\text { there are two } \\
\text { entrances }\end{array}$ \\
\hline & $\begin{array}{l}\text { Legibility of } \\
\text { composition }\end{array}$ & $\begin{array}{l}\text { YES/NO }(0.5) \\
\text { the } \\
\text { composition is } \\
\text { not entirely } \\
\text { legible, there } \\
\text { are } \\
\text { dead-ended } \\
\text { side paths }\end{array}$ & $\begin{array}{l}\text { YES (1) a clear } \\
\text { central path } \\
\text { with side paths }\end{array}$ & $\begin{array}{l}\text { YES (1) legible, } \\
\text { geometric } \\
\text { composition }\end{array}$ & $\begin{array}{l}\text { YES/NO (0.5) } \\
\text { consists of } \\
\text { several } \\
\text { sections, which } \\
\text { appear isolated } \\
\text { from each } \\
\text { other }\end{array}$ & $\begin{array}{l}\text { YES/NO (0.5) } \\
\text { consists of } \\
\text { several } \\
\text { sections which } \\
\text { do not appear } \\
\text { coherent }\end{array}$ & $\begin{array}{l}\text { YES/NO (0.5) } \\
\text { consists of } \\
\text { several } \\
\text { sections with } \\
\text { poor } \\
\text { compositional } \\
\text { linkages }\end{array}$ \\
\hline & $\begin{array}{l}\text { Presence of } \\
\text { water, } \\
\text { especially } \\
\text { water in } \\
\text { motion }\end{array}$ & $\mathrm{NO}(0)$ & $\mathrm{NO}(0)$ & $\mathrm{NO}(0)$ & $\begin{array}{l}\text { YES (1) there is } \\
\text { a fountain }\end{array}$ & $\mathrm{NO}(0)$ & $\begin{array}{l}\text { YES (1) there is } \\
\text { a fountain in } \\
\text { the form of } \\
\text { water jets }\end{array}$ \\
\hline & $\begin{array}{l}\text { Plant sensory } \\
\text { impact on each } \\
\text { of the senses }\end{array}$ & $\begin{array}{l}\text { YES/NO (0.5) } \\
\text { mostly a } \\
\text { scent-based } \\
\text { garden }\end{array}$ & $\begin{array}{l}\text { YES (1) each of } \\
\text { the five senses } \\
\text { is highlighted } \\
\text { in a separate } \\
\text { part of the } \\
\text { garden }\end{array}$ & $\begin{array}{l}\text { YES (1) plants } \\
\text { in pots provide } \\
\text { a diverse range } \\
\text { of sensations, } \\
\text { they can also } \\
\text { be tasted }\end{array}$ & $\begin{array}{l}\text { YES/NO (0.5) } \\
\text { various plants } \\
\text { that induce } \\
\text { sensory } \\
\text { experiences, no } \\
\text { experiences } \\
\text { based on taste }\end{array}$ & $\begin{array}{l}\text { YES/NO (0.5) } \\
\text { numerous } \\
\text { fragrant plants } \\
\text { and } \\
\text { fruit-bearing } \\
\text { bushes, one } \\
\text { can hear the } \\
\text { rustle of grass } \\
\text { and the sound } \\
\text { of gravel, but } \\
\text { touch is not } \\
\text { stimulated }\end{array}$ & $\mathrm{NO}(0)$ \\
\hline & $\begin{array}{l}\text { Intensity of } \\
\text { plant sensory } \\
\text { impact (e.g., } \\
\text { diversity of } \\
\text { species, large } \\
\text { spaces, } \\
\text { elevated beds) }\end{array}$ & $\begin{array}{l}\text { YES (1) large } \\
\text { patches of } \\
\text { fragrant plants } \\
\text { situated along } \\
\text { paths }\end{array}$ & $\begin{array}{l}\text { YES (1) wealth } \\
\text { of species and } \\
\text { strains; plants } \\
\text { also placed in } \\
\text { pots built into } \\
\text { benches }\end{array}$ & $\begin{array}{l}\text { YES (1) plants } \\
\text { elevated and } \\
\text { placed in large } \\
\text { pots }\end{array}$ & $\begin{array}{l}\text { YES (1) sensory } \\
\text { path } \\
\text { surrounded by } \\
\text { sensory active } \\
\text { plants }\end{array}$ & $\begin{array}{l}\text { YES/NO (0.5) } \\
\text { presence of } \\
\text { fragrant plants } \\
\text { in isolated } \\
\text { areas, but } \\
\text { difficult to } \\
\text { reach and } \\
\text { without seats }\end{array}$ & NO (0) absent \\
\hline
\end{tabular}


Table 4. Cont.

\begin{tabular}{|c|c|c|c|c|c|c|c|}
\hline \multicolumn{8}{|c|}{ The Second Group of Attributes } \\
\hline & & (A) & (B) & (C) & (D) & (E) & (F) \\
\hline \multicolumn{8}{|c|}{ Attribute } \\
\hline & $\begin{array}{l}\text { Other sensory } \\
\text { active elements } \\
\text { (e.g., labyrinth, } \\
\text { sensory path) }\end{array}$ & $\begin{array}{l}\text { YES (1) sensory } \\
\text { path and } \\
\text { labyrinths near } \\
\text { the garden }\end{array}$ & $\begin{array}{l}\text { YES (1) small } \\
\text { sensory path }\end{array}$ & NO (0) absent & $\begin{array}{l}\text { YES (1) sensory } \\
\text { path }\end{array}$ & $\begin{array}{l}\text { YES/NO (0.5) } \\
\text { observation } \\
\text { deck on roof, } \\
\text { with a gravel } \\
\text { surface, but } \\
\text { only accessible } \\
\text { via stairs }\end{array}$ & $\begin{array}{l}\text { YES (1) } \\
\text { labyrinth }\end{array}$ \\
\hline \multirow[t]{4}{*}{ Placemaking } & $\begin{array}{l}\text { Ability to } \\
\text { personalise the } \\
\text { space }\end{array}$ & $\mathrm{NO}(0)$ & $\mathrm{NO}(0)$ & $\mathrm{NO}(0)$ & $\mathrm{NO}(0)$ & $\mathrm{NO}(0)$ & $\mathrm{NO}(0)$ \\
\hline & $\begin{array}{l}\text { Ability to } \\
\text { animate the } \\
\text { space }\end{array}$ & $\begin{array}{l}\text { YES/NO (0.5) } \\
\text { lessons for } \\
\text { children, the } \\
\text { youth, or } \\
\text { adults in the } \\
\text { open }\end{array}$ & $\begin{array}{l}\text { YES (1) a green } \\
\text { meadow and a } \\
\text { tent from } \\
\text { living willow } \\
\text { branches form } \\
\text { a place for play } \\
\text { and recreation }\end{array}$ & $\begin{array}{l}\text { YES (1) } \\
\text { multimedia } \\
\text { presentations, } \\
\text { films on the } \\
\text { museum wall } \\
\text { (chairs laid out } \\
\text { on the lawn) }\end{array}$ & $\begin{array}{l}\text { YES/NO (0.5) } \\
\text { small tables } \\
\text { where one can } \\
\text { play board } \\
\text { games or chess }\end{array}$ & $\mathrm{NO}(0)$ & $\begin{array}{l}\text { YES (1) } \\
\text { potential to use } \\
\text { one's } \\
\text { imagination } \\
\text { and engage in } \\
\text { various forms } \\
\text { of play }\end{array}$ \\
\hline & $\begin{array}{l}\text { Artistic } \\
\text { creations }\end{array}$ & $\mathrm{NO}(0)$ & $\begin{array}{l}\text { YES (1) white } \\
\text { cubes that act } \\
\text { as seats }\end{array}$ & $\begin{array}{l}\text { YES (1) the } \\
\text { Museum wall } \\
\text { has an artistic } \\
\text { expression }\end{array}$ & $\mathrm{NO}(0)$ & $\mathrm{NO}(0)$ & $\mathrm{NO}(0)$ \\
\hline & $\begin{array}{l}\text { Special } \\
\text { indications for } \\
\text { use that } \\
\text { facilitate } \\
\text { experiencing } \\
\text { the garden } \\
\text { from up close }\end{array}$ & $\mathrm{NO}(0)$ & $\begin{array}{l}\text { YES (1) one can } \\
\text { taste fruits }\end{array}$ & $\begin{array}{l}\text { YES (1) one can } \\
\text { taste herbs }\end{array}$ & $\mathrm{NO}(0)$ & $\begin{array}{l}\text { YES (1) one can } \\
\text { taste fruits }\end{array}$ & $\begin{array}{l}\text { YES (1) one can } \\
\text { directly use all } \\
\text { the equipment, } \\
\text { including the } \\
\text { fountain }\end{array}$ \\
\hline \multirow[t]{4}{*}{$\begin{array}{l}\text { Sustainability } \\
\text { criteria }\end{array}$} & $\begin{array}{l}\text { Biodiversity } \\
\text { preservation: } \\
\text { use of } \\
\text { domestic plant } \\
\text { species and } \\
\text { plants } \\
\text { attractive to } \\
\text { various groups } \\
\text { of animals, } \\
\text { creating } \\
\text { habitats for } \\
\text { animals }\end{array}$ & $\begin{array}{l}\text { YES/NO (0.5) } \\
\text { some plants } \\
\text { are attractive } \\
\text { to butterflies or } \\
\text { other insects }\end{array}$ & $\begin{array}{l}\text { YES (1) } \\
\text { introduction of } \\
\text { plants } \\
\text { attractive to } \\
\text { the } \\
\text { hymenoptera } \\
\text { species, plants } \\
\text { with fruit for } \\
\text { birds; bird } \\
\text { habitats }\end{array}$ & $\begin{array}{l}\text { YES/NO (0.5) } \\
\text { intentional use } \\
\text { of species } \\
\text { attractive to } \\
\text { species of } \\
\text { hymenoptera }\end{array}$ & $\begin{array}{l}\text { YES/NO (0.5) } \\
\text { some plants } \\
\text { are attractive } \\
\text { to butterflies or } \\
\text { other insects }\end{array}$ & $\begin{array}{l}\text { YES/NO (0.5) } \\
\text { some plants } \\
\text { are attractive } \\
\text { to insects }\end{array}$ & $\mathrm{NO}(0)$ \\
\hline & $\begin{array}{l}\text { Sustainable } \\
\text { water } \\
\text { management, } \\
\text { e.g., } \\
\text { stormwater } \\
\text { collection and } \\
\text { use }\end{array}$ & $\mathrm{NO}(0)$ & $\mathrm{NO}(0)$ & $\mathrm{NO}(0)$ & $\mathrm{NO}(0)$ & $\mathrm{NO}(0)$ & $\mathrm{NO}(0)$ \\
\hline & $\begin{array}{l}\text { Natural energy } \\
\text { sources }\end{array}$ & $\begin{array}{l}\text { NOT } \\
\text { APPLICABLE- } \\
\text { no electrical } \\
\text { appliances }\end{array}$ & $\begin{array}{l}\text { NOT } \\
\text { APPLICABLE- } \\
\text { no electrical } \\
\text { appliances }\end{array}$ & $\mathrm{NO}(0)$ & $\mathrm{NO}(0)$ & $\mathrm{NO}(0)$ & $\mathrm{NO}(0)$ \\
\hline & $\begin{array}{l}\text { Natural garden } \\
\text { maintenance } \\
\text { methods }\end{array}$ & No data & No data & YES (1) & No data & No data & No data \\
\hline
\end{tabular}




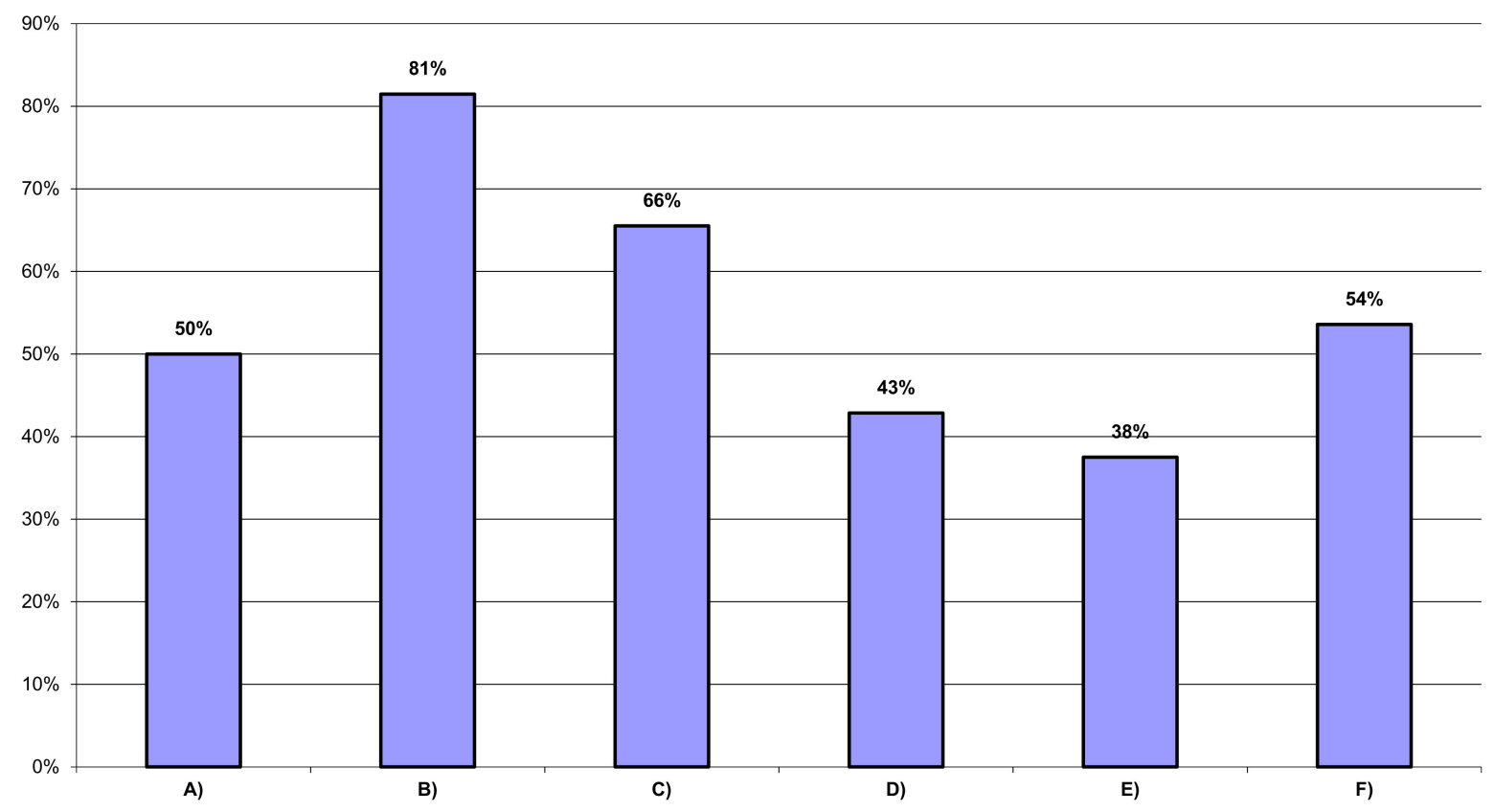

Figure 4. Presence of attributes that characterise the therapeutic spaces in each garden with sensory features in Kraków, in percentages. The letters A-F on the horizontal axis represent the gardens analysed; the description follows Figure 1.

The greatest number of attributes was found in the sensory garden at the Piaski Nowe housing estate. It was not given a perfect rating, as it did not feature any water features, including those based on stormwater. One of the least demanding solutions of this type could be a fountain for birds or for insects, with water obtained from waste, while more advanced water features include fountains, cascades, or flowing water. Following the principle that the more attributes a garden has, the better it is at performing its therapeutic function, it can be stated it was designed very well for this type of space. The deficiencies that were identified during assessment were not significant and making up for them is not impossible. We found it could be done without major changes to the garden's structure.

The least amount of points was given to two gardens that were recently built in city parks: Tysiąclecia Park and Reduta Park, as they had the lowest number of attributes. The most serious deficiency in both of them was that the sensory space was not isolated from the remainder of the parks. Isolation is a crucial characteristic of sensory gardens, and not providing it results in the gardens not having the atmosphere necessary to perceive the garden from up close and not receiving the resultant psychological regeneration. During a site visit we observed that dogs were allowed into these spaces and that people who crossed the park space were moving in a hurry. This indicates that these parks are often used as shortcuts to other destinations and visitors have no intention of using the therapeutic garden space.

In the case of the second garden, in Reduta Park, its designers used many bold and non-standard ideas (large areas covered by plants with edible fruit, a terrace with noisy gravel, or grass surrounding benches), yet their implementation, considering the failure to meet essential requirements of sensory gardens as therapeutic spaces, prevented a positive assessment.

The playground in H. Jordan Park has many features of a sensory garden. This garden could provide better sensory stimulation, both to children that visit the playground and to their caretakers, if it featured beds planted with stimulating plants.

Both gardens with sensory features that possessed intentionally placed elements that are friendly to pollinating insects, mainly those from the order hymenoptera and butterflies (the garden at the Piaski Nowe housing estate and near the J. Czapski Museum) were found to be places where pollinating insects visited flowering plants. Other sensory gardens (in the S. Lem Park, Tysiąclecia Park, and Reduta Park), despite not being inten- 
tionally designed as animal-friendly, fulfilled a similar role due to having large areas with blooming plants.

\section{Discussion}

The analytical tool based on Trojanowska's method [22] which we used to study Kraków's gardens with sensory features yielded results that are easy to list and allow for a quick comparison of each garden, combined with an identification of their weaknesses. This is due to the method employing a very good listing of therapeutic space attributes, which introduces a certain standardisation when studying structures of this type. This method also allows the list of attributes to be extended as the concept of therapeutic gardens evolves and develops, in addition to offering a better understanding of their potential while maintaining its value as an analytical tool. The potential of sensory gardens, both in generally accessible spaces and in healthcare and therapeutic facilities, has yet to be fully explored, with additional studies providing greater insight into their value and practical use [7].

However, it should be noted that this method was originally designed for studying public spaces. It may not be well suited to the study of gardens with sensory features that were designed to accompany healthcare and therapeutic facilities, as such gardens are prepared for highly specific users, who often suffer from health disorders and have special needs. When one designs a garden to accompany such an institution, the participation of their future users should be greater. Hussein argued that it is necessary to account for the therapeutic needs of specific patients, which is crucial to a positive outcome of their therapy [3,7], and Bengsston noted that such therapeutic gardens should be designed to offer patients a choice of activity and a sensory perception of the garden adapted to the level that they are currently capable of [23]. This means that such gardens should have a different structure than those located in public places.

The fifth group of attributes, namely accounting for sustainability precepts, was rated the lowest in the gardens under analysis. The first attribute, which concerns supporting biodiversity in sensory gardens, was found to be present only partially. The Polish-language literature highlights the significance of animal presence in therapeutic gardens [24]. It can even be suggested that it should be one of the essential characteristics of a sensory garden, as it considerably enhances the scope of sensory stimuli [17]. The presence of flowering and fruit-bearing plants in Kraków's gardens with sensory features supports urban fauna, especially insects and birds, which was visible in those gardens where specific plant species had been introduced (the garden in plant pots by the J. Czapski Museum and the garden at the Piaski Nowe housing estate). This is crucial in Kraków city parks, as beds with blooming plants are a rarity there. Furthermore, the lawns are intensively mowed, which is not conducive to plant species variety [25]. The use of ornamental plants aids in maintaining pollinator diversity, but only in the condition that the flowers have properties beneficial to them. Gardens intentionally designed as bee- or butterfly-friendly provide the best effect due to the use of species that are appropriate for them [26].

Sensory gardens have not been built in every urban activity zone in Kraków that could accommodate them. Other large cities around the world feature spaces for employees. New York provides the best practices in this regard, with its two pocket gardens: GreenAcre Park and Paley Park [8]. There are also cases of external green spaces accompanying places of employment, such as office gardens, which are sometimes built on rooftops and are dedicated solely to a given building's employees, of which London is a good example [27]. There are studies that show how crucial green surroundings are to office workers. They found that windows with a view of greenery and indoor plants visibly reduced workplace stress [28]. The ability to spend one's lunchbreak or free time in a sensory garden space would be all the more beneficial. Of the gardens under analysis, the garden near the J. Czapski Museum is the closest to this concept, although it is not a typical garden dedicated to employees. It was constructed in the city centre and includes a coffee shop terrace that is a part of the Museum, which allows visitors to spend more time in a sensory environment. 


\section{Conclusions}

The method we used in this study allowed us to critically assess these complexes, which can enable the introduction of specific changes, as they can be easily identified as attributes. Thus, the method can be used both to study completed gardens and earlier. during the design phase. It can therefore be used in practice. It can be said that there is a need to apply it, as demonstrated by the latest gardens with sensory features that have been built in Kraków, and which have visible, essential deficiencies that prevent making use of their full potential as sensory spaces.

The method is not only a practical tool but also he proposal of an academic method (an analytical procedure that can be used in investigations) that allows for an in-depth analysis of such gardens.

In Poland, a country that has only recently began introducing sensory gardens into public spaces, the evolution of this concept has started to develop rapidly, and Kraków's gardens are not copies of some specific scheme. They include a variety of solutions in terms of layout and sensory stimulus sources.

Author Contributions: Investigation: I.K.-M., Ł.M., K.P.; Methodology: I.K.-M., Ł.M.; Visualization: K.P., Ł.M.; Writing—original draft: I.K.-M.; Writing—review \& editing: K.P. All authors have read and agreed to the published version of the manuscript.

Funding: This research received no external funding.

Institutional Review Board Statement: Not applicable.

Informed Consent Statement: Not applicable.

Data Availability Statement: The study did not report any data.

Conflicts of Interest: The authors declare no conflict of interest.

\section{References}

1. Winterbottom, D.; Wagenfeld, A. Therapeutic Gardens: Design for Healing Spaces; Timber Press: Portland, OR, USA, 2015.

2. Ulrich, R.S. Health Benefits for Gardens in Hospitals. Ph.D. Thesis, Texas A \& M University, College State, TX, USA, 2002.

3. Hussein, H. Using the sensory garden as a tool to enhance the educational development and social interaction of children with special needs. Support Learn. 2010, 25, 25-31. [CrossRef]

4. Gonzalez, M.T.; Kirkevold, M. Clinical use of sensory gardens and outdoor environment in Norvegian nursing homes: A cross-sectional e-mail survey. Issues Ment. Health Nurs. 2015, 36, 35-43. [CrossRef] [PubMed]

5. Balode, L. The design guidelines for therapeutic sensory gardens. Res. Rural Dev. 2013, 2, 114-119.

6. Sensory Trust. Available online: Sensorytrust.org.uk/information/factsheets/sensory-garden-1.html (accessed on 21 January 2021).

7. Hussein, H. Sensory Garden in Special Schools: The issues, design and use. J. Des. Built Environ. 2009, 5, 77-95.

8. Pawłowska, K. Ogród sensoryczny. In Dźwięk w Krajobrazie Jako Przedmiot Badań Interdyscyplinarnych. Prace Komisji Krajobrazu Kulturowego PTG; Bernat, S., Ed.; Wydawnictwo Polihymnia: Lublin, Poland, 2008; Volume XI, pp. 143-152.

9. Dudkiewicz, M.; Marcinek, B.; Tkaczyk, A. Idea ogrodu sensorycznego w koncepcji zagospodarowania atrium przy Szpitalu Klinicznym nr 4 w Lublinie. Acta Sci. Pol. Archit. 2014, 13, 71-77.

10. Górska-Kłęk, L. ABC Zielonej Opieki. Seria „Biblioteka Nestora”, t. VIII; Dolnośląski Ośrodek Polityki Społecznej: Wrocław, Poland, 2016; p. 151.

11. Trojanowska, M. Parki i Ogrody Terapeutyczne; Wydawnictwo Naukowe PWN SA: Warszawa, Poland, 2017 ; p. 231.

12. Dąbski, M.; Dudkiewicz, M. Przystosowanie ogrodu dla niewidomego użytkownika na przykładzie ogrodów sensorycznych w Bolestraszycach, Bucharzewie i Powsinie. Teka Kom. Archit. Urban. Studiów Kraj. 2010, 6, 7-17.

13. Trojanowska, M. Sensory gardens inclusively designed for visually impaired users. PhD Interdiscip. J. $2014,1,30-317$.

14. Woźny, A.; Lauda, A. Ogrody dla osób z dysfunkcją wzroku w świetle ich oczekiwań. Archit. Kraj. 2014, 4, 65-71.

15. Zajadacz, A.; Lubarska, A. Sensory gardens as places for outdoor recreation adapted to the needs of people with visual impairments. Studia Perieget. 2020, 2, 25-43. [CrossRef]

16. Westphal, J.M. Hype, Hyperbole, and Health: Therapeutic site design. In Urban Lifestyles: Spaces, Places People; Benson, J.F., Rowe, M.H., Eds.; Brookfield A. A. Balkema: Rotterdam, The Netherlands, 2000.

17. Krzeptowska-Moszkowicz, I.; Moszkowicz, Ł.; Porada, K. Znaczenie miejskich ogrodów sensorycznych o cechach przyjaznych organizmom rodzimym, na przykładzie dwóch przypadków z terenu dużych miast europejskich: Krakowa i Londynu. In Integracja Sztuki i Techniki w Architekturze i Urbanistyce; Wydawnictwa Uczelniane Uniwersytetu Technologiczno-Przyrodniczego: Bydgoszcz, Poland, 2020; pp. 61-69. 
18. Kuczko, D. Ogrody sensoryczne na Błoniach Niepołomickich; Cracow University of Technology: Kraków, Poland, 2005.

19. Kraków w Liczbach. 2019, Urząd Miasta Krakowa. Available online: https:/ / www.bip.krakow.pl/?mmi=6353 (accessed on 21 January 2021).

20. Kondracki, J. Geografia Regionalna Polski; Polskie Wydawnictwo Naukowe: Warszawa, Poland, 2001; p. 441.

21. Rackiewicz, I. Diagnoza Stanu Środowiska Miasta Krakowa; Urząd Miasta Krakowa: Kraków, Poland, 2012.

22. Trojanowska, M. The Universal Pattern of Design for Therapeutic Parks. Methods of Use. Int. J. Sci. Eng. Res. 2018, 9, 1410-1413.

23. Bengtsson, A.; Grahn, P. Outdoor environments in healthcare settings: A quality evaluation tool for use in designing healthcare gardens. Urban For. Urban Green. 2012, 13, 878-891. [CrossRef]

24. Nowacki, J.; Bunalski, M.; Sienkiewicz, P. Fauna jako istotny element hortiterapii. In Hortiterapia Jako Element Wspomagajacy Leczenie Tradycyjne; Krzymińska, A., Ed.; Rhytmos: Poznań, Poland, 2012; pp. 117-144.

25. Moszkowicz, Ł.; Krzeptowska-Moszkowicz, I. Impact of the public parks location in the city on the richness and diversity of herbaceous vascular plants on the example of Krakow Southern Poland. In Proceedings of the Plants in Urban Areas and Landscape, Nitra, Slovakia, 7-8 November 2019. [CrossRef]

26. Willmer, P. Pollination and Floral Ecology; Princeton University Press: Princeton, NJ, USA; Oxford, UK, $2011 ;$ p. 778.

27. Chance, H.; Winterbottom, D.; Bell, J.; Wagenfeld, A. Gardens for Well-Being in Workplace Environments. In Proceedings of the 3rd European Conference on Design4Health, Sheffield, UK, 13-16 July 2015. Available online: https:/ / research.shu.ac.uk/ design4health/wp-content/uploads/2015/07/D4H_Chance_et_al.pdf (accessed on 1 September 2020).

28. Chang, C.Y.; Chen, P.K. Human Response to window views and indoor plants in the workplace. HortScience 2005, 40, 1354-1359. [CrossRef] 